\title{
ANALISIS FAKTOR YANG BERHUBUNGAN DENGAN KELUHAN SUBJEKTIF FOTOKERATITIS PADA PEKERJA PENGELASAN DI KOTA KENDARI TAHUN 2020
}

\author{
ANAL YSIS OF FACTORS RELATED TO SUBJECTIVE COMPLAINTS OF \\ PHOTOKERATITIS IN WELDING WORKERS OF KENDARI CITY IN 2020
}

\author{
Hastin', *Pitrah Asfian², Fikki Prasetya ${ }^{3}$ \\ 12 Peminatan Kesehatan dan Keselamatan Kerja Prodi Kesmas FKM ; Universitas Halu Oleo Kendari, Indonesia \\ ${ }^{3}$ Peminatan Promosi Kesehatan Prodi Kesmas FKM ; Universitas Halu Oleo Kendari, Indonesia \\ 1'hastinrahim@gmail.com, ${ }^{2}$ pitrahasfian@gmail.com, ${ }^{3}$ fikki85@gmail.com
}

\section{*Correspondence Author}

Pitrah Asfian

Peminatan Kesehatan dan Keselamatan Kerja Prodi Kesmas FKM, Universitas Halu Oleo Kendari, Indonesia Email : pitrahasfian@gmail.com

\begin{abstract}
Abstrak
Fotokeratitis adalah kerusakan pada kornea mata akibat cahaya, yang diakibatkan oleh paparan sinar matahari yang berlebihan atau sumber sinar UV buatan lainnya. Sinar UV yang ditangkap oleh mata akan di serap oleh lapisan jaringan terluar kornea dan konjungtiva. Adapun gejala yang ditimbulkan berupa memerahnya bola mata, rasa sakit pada mata, mata terasa berpasir, banyak mengeluarkan air mata, dan penglihatan terasa kabur. Penelitian ini dilakukan untuk mengetahui hubungan antara lama paparan, jarak pengelasan, getaran dan penggunaan APD pada pekerja pengelasan Kota Kendari tahun 2020. Penelitian ini merupakan penelitian cross sectional study. Populasi dalam penelitian ini adalah 52 orang dan sampel yang diambil menggunakan stratified random sampling. Hasil uji statistik pada tingkat signifikan $\alpha=0,05$ diperoleh hasil, ada hubungan yang bermakna antara lama paparan $\left(\rho_{\text {value }}=0,005\right)$, jarak pengelasan $\left(\rho_{\text {value }}=0,008\right)$, dan penggunaan APD $\left(\rho_{\text {value }}=0,044\right)$ dengan keluhan subjektif fotokeratitis. Tidak ada hubungan yang bermakna antara getaran $\left(\rho_{\text {value }}=0,739\right)$ dengan keluhan subjektif fotokeratitis. Hasil analisis multivariat menunjukan ada pengaruh lama paparan $\left(\rho_{\text {value }}=0,012\right.$, OR=6,490), jarak pengelasan $\left(\rho_{\text {value }}=0,007, \mathrm{OR}=8,776\right)$ dan penggunaan APD $\left(\rho_{\text {value }}=0,027, O R=0,173\right)$ terhadap keluhan subjektif fotokeratitis. Kesimpulan dari penelitian ini yaitu ada hubungan antara lama paparan, jarak pengelasan, dan penggunaan APD dengan keluhan subjektif fotokeratitis pada pekerja pengelasan di Kota Kendari. Serta tidak ada hubungan antara getaran dengan keluhan subjektif fotokeratitis pada pekerja pengelasan di Kota Kendari. Ada pengaruh antara lama paparan, jarak pengelasan dan penggunaan APD dengan keluhan subyektif fotokeratitis pada pekerja pengelasan di Kota Kendari.
\end{abstract}

Kata kunci: APD, Fotokeratitis, Getaran, Jarak Pengelasan, Lama Paparan

\begin{abstract}
Photokeratitis is an inflammation of the cornea due to light, which is caused by sunlight or other artificial UV light sources. UV rays captured by the eye are absorbed by the outer tissue layer of the corneal and the conjunctiva, reaching slightly to the lens or the inner part of the eye. This research was conducted to determine the relationship between the length of exposure, welding distance, vibration, and the use of personal protective equipment on the welding worker of Kendari city in 2020. This research is a cross-sectional study. The population in this study was 52 and samples were taken using stratified random sampling. The results of the statistical test at a significant level of $\alpha=0.05$ obtained results, there is a meaningful relationship between the length of exposure $\left(\rho_{\text {value }}=0,005\right)$, the welding distance $\left(\rho_{\text {value }}=0,008\right)$, and the use of personal protective equipment $\left(\rho_{\text {value }}=0,044\right)$ with a subjective complaint of Photokeratitis. There is no meaningful relationship between vibration $\left(\rho_{\text {value }}=0,739\right)$ with photokeratitis subjective complaints. The result of multivariate analysis shows that there is an effect of prolonged exposure $\left(\rho_{\text {value }}=0,012, O R=6,490\right)$, the welding distance $\left(\rho_{\text {value }}=0,007, O R=8,776\right)$ and the use of personal protective equipment ( $\rho_{\text {value }}=0,027, O R=0,173$ ) against the subjective complaint of Photokeratitis. This study concludes that there is a relationship between duration of exposure, welding distance, and use of personal protective equipment with subjective complaints of photokeratitis in kendari city. And there is no relationship between vibration and subjective complaints of photokeratitis in kendari city. There is an influence duration of exposure, welding distance, and use of personal protective equipment with subjective complaints of photokeratitis in kendari city.
\end{abstract}

Keywords: Length of exposure, photokeratitis, personal protective equipment, vibration, welding distance 


\section{Pendahuluan}

Keselamatan dan Kesehatan Kerja (K3) merupakan hal yang tidak terpisahkan dalam sistem ketenagakerjaan dan sumber daya manusia. Keselamatan dan Kesehatan Kerja (K3) tidak saja sangat penting dalam meningkatkan jaminan sosial dan kesejahteraan para pekerjanya akan tetapi jauh dari itu keselamatan dan kesehatan kerja berdampak positif atas keberlanjutan produktifitas kerja. Oleh sebab itu, isu keselamatan dan kesehatan kerja pada saat ini bukan sekedar kewajiban yang harus diperhatikan oleh para pekerja, akan tetapi juga harus dipenuhi oleh sebuah sistem pekerjaan (1).

Radiasi ultraviolet yang dihasilkan dari pengelasan dapat menyebabkan gangguan akut ditempat kerja, seperti kerusakan pada mata yang ditandai dengan gejala perih, berair, mata terasa berpasir dan photopobia. Berdasarkan survey photokeratokonjungtivitis dari The Japan Welding Engiuneering Society (JWES,1980) menemukan bahwa sekitar 86\% dari pekerja pengelasan memiliki pengalaman kerja dan sekitar $45 \%$ mengalami gejala lebih dari sekali dalam sebulan. Meskipun demikian, dengan melihat besarnya populasi yang beresiko maka akan banyak kasus photokeratokonjungtivitis yang dapat terjadi ditempat kerja pengelasan (2).

Fotokeratitis adalah inflamasi akut pada kornea dan konjungtiva yang akan timbul setelah mata terkena pajanan bunga api pengelasan pada jarak yang dekat. Fotokeratitis merupakan eye injury yang sering menyebabkan turunnya kemampuan melihat yang disebabkan oleh radiasi sinar ultraviolet menyebabkan gejala-gejala seperti mata perih, berair, mata terasa berpasir dan fotofobia (3).
Berdasarkan data U.S Departemen Labour pada tahun 2015 melaporkan bahwa cidera mata dapat menyebabkan kerugian financial yakni sebesar 300 juta dollar/tahun akibat dari hilangnya hari kerja, pembayaran biaya perawatan, dan biaya ganti rugi pada pekerja. Berdasarkan data Bureau Labor Statistik (BLS) pada tahun 2016, bahwa terjadi injury mata sekitar $37 \%$ dari kejadian injury pada bagian kepala dan mengakibatkan hilangnya hari kerja. Apabila dilihat dari karasteristik pekerja bahwa cidera mata yang terjadi pada laki-laki lebih berisiko dibandingkan cidera mata pada perempuan, yaitu sekitar $81 \%$. Kebanyakan injury mata terjadi pada pekerja yang berumur antara 25-44 tahun (4).

Penelitian yang dilakukan oleh Nur Najmi Laila pada tahun 2017 pada pekerja las di Kelurahan Cideru dan Ciputat Tangerang Selatan dengan jumlah responden sebanyak 20 orang $(62.5 \%)$ dari 32 pekerja mengalami keluhan subjektif photokeratitis yang tidak mengeluhkan adalah sebanyak 12 orang $(37.5 \%)$. Keluhan subjektif fotokeratitis yang paling banyak dikeluhkan adalah rasa silau sebanyak 22 orang (68.8\%) kemudian rasa ada benda asing seperti pasir sebanyak 18 responden (56.2\%), terasa perih 17 orang (53.1\%) (5).

Hasil penelitian yang dilakukan oleh Wahyuni (2012) terhadap tukang las di sepanjang jalan Bogor, didapatkan 73,3\% pekerja mengalami kejadian fotokeratitis. Rizwaningrum (2012) memperoleh hasil penelitian bahwa lebih dari separuh pekerja bengkel las konstruksi wilayah Puskesmas Ambang mengalami kejadian mata yang menyerupai keluhan subjektif fotokeratitis. Penelitian tentang gambaran faktor resiko 
sindrom fotokeratitis pada pekerja las di PT. Industri Kapal Indonesia (Persero) Kota Makassar menunjukan terdapat 23 responden $(85,5 \%)$ yang terkena sindrom fotokeratitis dan 3 responden (11,5\%) yang tidak terkena sindrom fotokeratitis. Terdapat 10 responden $(38,5 \%)$ yang beresiko menurut usia dan 16 responden $(61,5 \%)$ yang tidak beresiko terkena sindrom'fotokeratitis, 20 responden (76,9\%) yang beresiko dan 6 responden (23,1\%) yang tidak beresiko menurut masa kerja, 26 responden (100\%) beresiko berdasarkan lama paparan, 26 responden (100\%) beresiko menurut besar radiasi ultraviolet, 22 responden $(84,6 \%)$ beresiko dan 4 responden $(15,4 \%)$ beresiko menurut jarak pengelasan (2).

Berdasarkan survei awal yang dilakukan oleh penulis pada beberapa pekerja las di Kota Kendari menunjukan bahwa sebagian besar pekerja las bekerja tidak sesuai prosedur, banyak yang tidak memperhatikan keselamatan dan kesehatan pada dirinya sendiri, seperti : tidak memakai alat pelindung diri khusus untuk pengelasan (safety welding) yaitu kecamata las berbahan trivex dan tidak memakai masker khusus pengelasan. Berdasarkan data awal yang diperoleh dari kuisioner sebanyak 20 pekerja dan terdapat 16 pekerja mengalami gangguan mata seperti mata merah, mata terasa berpasir, mata sering berair, silau saat melihat, kelopak mata terasa bengkak, merasakan panas pada mata, mata terasa perih dan merasakan penglihatan terasa kabur. Rata-rata di antara mereka merasakan gangguan ini pada malam hari setelah mengelas. Hal itu sejalan dengan ciri-ciri keluhan subjektif fotokeratitis.

Mengacu pada uraian diatas maka peneliti merasa tertarik untuk melakukan penelitian yang bertujuan untuk menganalisis faktor yang
Jurnal Kesehatan dan Keselamatan Kerja Universitas Halu Oleo Volume 1 No 3 Oktober 2020

Published by FKM UHO

e-ISSN : 2723-519X; page 117-124

berhubungan dengan keluhan subjektif fotokeratitis pada pekerja pengelasan di Kota Kendari tahun 2020

\section{Metode}

Jenis penelitian ini adalah penelitian analitik dengan pendekatan cross sectional study (potong lintang) yaitu penelitian yang bertujuan untuk mengetahui faktor yang berhubungan dengan keluhan subjektif fotokeratitis pada pekerja pengelasan di Kota Kendari. Penelitian ini dilaksanakan pada bulan januari 2020 dan berlokasi di bengkel las yang terdapat di wilayah Kota Kendari, Sulawesi Tenggara. Variabel dalam penelitian ini yaitu keluhan subjektif fotokeratitis, lama paparan, penggunaan APD yang diukur dengan menggunakan kuisioner, jarak pengelasan yang diukur dengan menggunakan meter dan getaran yang diukur dengan menggunakan vibrasi meter. Sampel dalam penelitian ini adalah berjumlah 52 orang. Sumber data dalam penelitian ini terdiri dari sumber data primer dan sumber data sekunder. Sumber data primer diperoleh jika responden setuju untuk menjadi reponden dalam penelitian ini. Data primer dalam penelitian ini adalah keluhan subjektif fotokeratitis, lama paparan, jarak pengelasan, getaran dan penggunaan APD. Untuk data sekunder yaitu berupa data yang diperoleh dari instansi terkait yang ada hubungannya dengan penelitian ini. Keluhan subjektif fotokeratitis dalam penelitian ini adalah gangguan pada mata yang dirasakan oleh pekerja pengelasan selama tiga bulan terakhir yang dikur menggunakan kuisioner keluhan subjektif fotokeratitis dikategorikan menjadi jika ada keluhan $\geq 3$ gejala dan tidak ada keluhan $<3$ gejala. Lama paparan adalah lama pekerja terpapar radiasi sinar UV dalam satu kali pengelasan dalam sehari, angka diperoleh dari 
hasil pengisian kuisioner. Lama paparan dikategorikan menjadi $>40$ menit dan $\leq 40$ menit. Jarak pengelasan adalah jarak antara mata pekerja dengan sumber penghasil radiasi yang diukur menggunakan meter dengan satuan $\mathrm{cm}$. Jarak pengelasan dikategorikan menjadi $>52$ $\mathrm{cm}$ dikatakan berisiko tinggi dan $\leq 52 \mathrm{~cm}$ berisiko rendah. Getaran adalah suatu getaran yang dihasilkan oleh mesin yang diukur denga menggunakan vibrasi meter tipe $8201 \mathrm{HA}$ dikatakan berisiko jika getaran $\geq 4 \mathrm{~m} / \operatorname{det}^{2}$ dan tidak berisiko jika getaran $\leq 4 \mathrm{~m} / \mathrm{det}^{2}$. Penggunaan APD adalah peralatan pelindung diri yang digunakan pada saat bekerja. Variabel ini diukur menggunakan kuisioner. Dikatakan patuh apabila seorang pekerja menggunakan
APD dengan baik dan memakai kecamata las pada saat bekerja, dikatakan tidak patuh jika tidak memakai APD dengan baik. Seluruh data dalam penelitian ini adalah data primer yang diperoleh langsung dari responden. Data dianalisis dengan menggunakan uji statistic dengan uji chi square. Data dikumpulkan dengan menggunakan kuisioner dan pengukuran. Kuisioner untuk variabel keluhan subjektif fotokeratitis, lama paparan dan penggunaan APD. Sedangkan pengukuran untuk mengumpulkan variabel jarak pengelasan dan getaran. Adapun analisis data dalam penelitian ini yaitu analisis univariat, analisis bivariat dan analisis multivariat.

\section{Hasil dan Pembahasan}

Tabel 1. Distribusi Hubungan Keluhan Subjektif Fotokeratitis, Lama Paparan, Jarak Pengelasan, Getaran dan Penggunaan APD pada Pekerja Pengelasan di Kota Kendari Tahun 2020

\begin{tabular}{lcc}
\hline \multicolumn{1}{c}{ Variabel } & Jumlah (n) & Persentase (\%) \\
\hline Keluhan Subjektif Fotokerastitis & & \\
Ada Keluhan & 33 & 63,5 \\
Tidak Ada Keluhan & 19 & 36,5 \\
$\quad$ Total & 52 & 100 \\
\hline Lama Paparan & & \\
Berisiko & 31 & 59,6 \\
$\quad$ Tidak Berisiko & 21 & 40,4 \\
$\quad$ Total & 52 & 100 \\
\hline Jarak Pengelasan & & \\
Risiko Tinggi & 35 & 67,3 \\
Risiko Rendah & 17 & 32,7 \\
Total & 52 & 100 \\
\hline Getaran & & \\
Berisiko & 19 & 36,5 \\
Tidak Berisiko & 33 & 63,5 \\
$\quad$ Total & 52 & 100 \\
\hline Penggunaan APD & & \\
Patuh & 30 & 57,6 \\
Tidak Patuh & 22 & 42,3 \\
Total & 52 & 100 \\
\hline
\end{tabular}

Tabel 1 menunjukkan dari 52 responden terdapat 33 responden $(63,5 \%)$ mengalami keluhan subjektif fotokeratitis yakni memiliki $\geq 3$ keluhan gejala fotokeratitis dan 19 responden $(36,5 \%)$ tidak mengalami keluhan subjektif fotokeratitis karena hanya memiliki 3 atau kurang gejala keluhan subjektif fotokeratitis

Berdasakan lama paparan menunjukan bahwa sebagian besar responden memiliki lama paparan yang berisiko yakni sebanyak 31 
orang $(59,6 \%)$ dan lama paparan yang tidak berisiko sebanyak 21 orang $(40,4 \%)$.

Berdasarkan jarak pengelasan menunjukan bahwa sebagian besar responden memiliki jarak pengelasan yang berisiko tinggi yakni sebanyak 35 orang $(67,3 \%)$ dan jarak pengelasan yang berisiko rendah sebanyak 17 orang $(32,7 \%)$.

Berdasarkan getaran menunjukan bahwa sebagian besar responden memiliki frekuensi getaran yang tidak berisiko sebanyak 33 orang $(63,5 \%)$ dan berisiko sebanyak 19 orang
$(36,5 \%)$.

Berdasarkan penggunaan alat pelindung diri (APD) menunjukan bahwa dari 52 responden terdapat 30 responden $(57,6 \%)$ yang patuh menggunakan alat pelindung diri pada saat melakukan pengelasan dan 22 responden $(42,3 \%)$ yang tidak patuh menggunakan alat pelindung diri pada saat melakukakn pengelasan.

Tabel 2. Analisis Hubungan Lama Paparan, Jarak Pengelasan, Getaran, Penggunaan APD dengan Terjadinya Keluhan Subjektif Fotokeratitis pada Pekerja Pengelasan di Kota Kendari Tahun 2020

\begin{tabular}{|c|c|c|c|c|c|c|c|}
\hline \multirow{3}{*}{ Variabel } & \multicolumn{4}{|c|}{ Keluhan Subjektif Fotokeratitis } & \multirow{2}{*}{\multicolumn{2}{|c|}{ Total }} & \multirow{3}{*}{$\rho_{\text {value }}$} \\
\hline & \multicolumn{2}{|c|}{ Ada Keluhan } & \multicolumn{2}{|c|}{$\begin{array}{c}\text { Tidak Ada } \\
\text { Keluhan }\end{array}$} & & & \\
\hline & $\mathbf{n}$ & $\%$ & $\mathbf{N}$ & $\%$ & $\mathbf{N}$ & $\%$ & \\
\hline \multicolumn{8}{|l|}{ Lama Paparan } \\
\hline Berisiko & 25 & 80,6 & 6 & 19,4 & 31 & 100 & \multirow{3}{*}{0,005} \\
\hline Tidak Berisiko & 8 & 39,1 & 13 & 61,9 & 21 & 100 & \\
\hline Total & 33 & 63,5 & 19 & 36,5 & 52 & 100 & \\
\hline \multicolumn{8}{|l|}{ Jarak Pengelasan } \\
\hline Risiko Tinggi & 27 & 77,1 & 8 & 12,8 & 35 & 100 & \multirow{3}{*}{0,008} \\
\hline Risiko Rendah & 6 & 35,5 & 11 & 64,7 & 17 & 100 & \\
\hline Total & 33 & 63,5 & 19 & 36,5 & 52 & 100 & \\
\hline \multirow{2}{*}{\multicolumn{8}{|c|}{ Getaran }} \\
\hline Berisiko & 11 & 57,9 & & & & & \multirow{3}{*}{0,739} \\
\hline Tidak Berisiko & 22 & 66,7 & 11 & 33,3 & 33 & 100 & \\
\hline Total & 33 & 63,5 & 19 & 36,5 & 52 & 100 & \\
\hline \multicolumn{8}{|l|}{ Penggunaan APD } \\
\hline Patuh & 23 & 76,7 & 7 & 23,3 & 30 & 100 & \multirow{3}{*}{0,044} \\
\hline Tidak Patuh & 10 & 45,5 & 12 & 54,5 & 22 & 100 & \\
\hline Total & 33 & 63,5 & 19 & 36,5 & 52 & 100 & \\
\hline
\end{tabular}

Lama paparan adalah lama pekerja terpapar radiasi sinar UV dalam satu kali pengelasan. Kerusakan yang ditimbulkan akibat radiasi UV terhadap mata tergantung besarnya intensitas radiasi dan lama paparan.

Penelitian ini dilakukan di Bengkel Las Kota Kendari pada pekerja pengelasan sebanyak 52 orang. Hasil penelitian menunjukan mayoritas responden memiliki lama paparan sinar UV lebih dari nilai ambang batas (NAB). Hal ini di karenakan waktu kerja seseorang dalam sehari akan lebih rentan terpapar oleh radiasi, sehingga menimbulkan banyaknya radiasi yang diterima maka akan sangat berisiko terhadap kesehatan, karena semakin lama seseorang terpapar radiasi maka semakin tinggi risiko terkena keluhan subjektif fotokeratitis (6).

Berdasarkan hasil uji chi square, disimpulkan bahwa ada hubungan antara lama 
paparan dengan terjadinya keluhan subjektif fotokeratitis pada pekerja pengelasan di Kota Kendari Tahun 2020, dimana nilai hubungan kedua variabel bernilai $\left(\rho_{\text {value }}=0,005\right)$ dengan demikian maka $\mathrm{H}_{0}$ ditolak atau $\mathrm{H}_{\mathrm{a}}$ diterima. Penelitian ini sejalan dengan Susanto (2015) menyatakan ada hubungan antara lama seseorang bekerja dengan keluhan photokeratokonjungtivitis pada pekerja las.

Jarak pengelasan adalah salah satu faktor yang mempengaruhi besarnya intensitas radiasi sinar UV terhadap mata, dimana jarakk 35-52 $\mathrm{cm}$ merupakan jarak sumber radiasi sinar UV yang masih termasuk yang berisiko mengalami keluhan subjektif fotokeratitis (7).

Berdasarkan hasil uji chi square didapatkan bahwa nilai $\rho$ value $<\alpha$ sehingga terdapat hubungan jarak pengelasan dengan terjadinya keluhan subjektif fotokeratitis pada pekerja pengelasan di Kota Kendari tahun 2020, dimana nilai hubungan kedua variabel bernilai $(\rho$ value $=0,008)$ dengan demikian maka $\mathrm{H}_{0}$ ditolak atau $\mathrm{H}_{\mathrm{a}}$ diterima. Penelitian ini sejalan dengan Adip Firmansah (2015) dalam penelitiannya dibengkel las Kota Jember menyimpulkan bahwa terdapat hubungan antara jarak pengelasan dengan terjadinya keluhan subjektif fotokeratitis. Semakin dekat jarak melakukan pengelasan maka akan semakin tinggi risiko terkena keluhan subjektif fotokeratitis.

Berdasarkan penelitian yang dilakukan sebagian besar pekerja melakukan pengelasan < $52 \mathrm{~cm}$, mempunyai risiko gangguan mata yang diakibatkan terlalu dekatnya jarak dengan media pengelasan, sehingga mata menerima intensitas cahaya lebih besar dan akan mengalami kelelahan pada mata. Hal ini dapat menyebabkan keluhan subjektif fotokeratitis

Getaran adalah adalah gerakan yang berulang memutar kedepan pada mesin sehingga menghasilkan suatu getaran dan mengganggu atau membahayakan kesehatan (8).

Getaran mekanis dapat diartikan sebagai getaran yang ditimbulkan oleh alat-alat mekanis, yang sebagian dari getaran ini sampai ketubuh dan dapat menimbulkan akibat-akibat yang tidak diinginkan pada tubuh kita. Getaran yang melebihi nilai ambang batas dapat menyebabkan kelelahan mata ditandai dengan gejala penurunan, ketajaman mata, penglihatan rangkap atau kabur, sakit atau pegal di sekitar mata dan terjadinya kesalahan atau bahkan kecelakaan kerja (9).

Berdasarkan hasil uji chi square didapatkan bahwa nilai $\rho_{\text {value }}>\alpha$ sehingga tidak terdapat hubungan getaran dengan terjadinya keluhan subjektif fotokeratitis pada pekerja pengelasan di Kota Kendari tahun 2020, dimana nilai hubungan kedua variabel bernilai $(\rho$ value $=0,739)$ dengan demikian maka $H_{0}$ diterima atau $\mathrm{H}_{\mathrm{a}}$ ditolak. Berdasarkan penelitian yang dilakukan pada pekerja pengelasan di Kota Kendari bahwa tidak ada hubungan antara getaran dengan keluhan subjektif fotokeratitis, dikarenakan getaran mesin lebih berisiko terhadap tubuh seperti pada tangan atau lengan karena bersentuhan langsung dengan media getaran.

Alat pelindung diri (APD) adalah seperangkat alat keselamatan yang digunakan oleh pekerja, untuk melindungi seluruh atau sebagian tubuhnya dari kemungkinan adanya paparan potensi bahaya lingkungan kerja terhadap kecelakaan dan penyakit akibat kerja (10).

Berdasarkan hasil uji chi square didapatkan bahwa nilai $\rho$ value $<\alpha$ terdapat hubungan antara penggunaan APD dengan 
terjadinya keluhan subjektif fotokeratitis pada pekerja pengelasan di Kota Kendari tahun 2020, dimana nilai hubungan kedua variabel bernilai $(\rho$ value $=0,044)$ dengan demikian maka $\mathrm{H}_{0}$ ditolak atau $\mathrm{H}_{\mathrm{a}}$ diterima. Penelitian ini sejalan dengan Priyanto (2016), menyatakan terdapat hasil yang signifikan antara responden yang tidak disiplin menggunakan alat pelindung diri dengan responden yang disiplin menggunakan alat pelindung diri dengan terjadinya sindrom photokeratitis.

Kedisiplinan banyak mempengaruhi terjadinya keluhan subjektif fotokeratitis pada pekerja las. Berdasarkan hasil penelitian, ditemukan 22 responden yang tidak menggunakan APD dengan baik dan tidak sesuai standar, bahkan mereka menyimpan APD (kecamata las) disembarang tempat. Hal ini menunjukan kurangnya kesadaran, pengetahuan, serta aturan yang ditetapkan oleh pihak industri belum diperhatikan khususnya untuk kesehatan para pekerja untuk lebih produktif. Berdasarkan pernyataan dari responden mereka tidak menggunakan APD dikarenakan kurang nyaman dan sudah menjadi kebiasaan.

Tabel 3. Hasil Analisis Multivariat Antara Variabel Bebas dengan Keluhan Subjektif Fotokeratitis pada Pekerja Pengelasan di Kota Kendari Tahun 2020

\begin{tabular}{ccccccc}
\hline Variabel & B & \multirow{2}{*}{ Wald } & Nilai P & OR $\operatorname{Exp}(\mathrm{B})$ & \multicolumn{2}{c}{$95 \% \mathrm{Cl}$} \\
\hline Lama paparan & 1,870 & 6,263 & 0,012 & 6,490 & 1,500 & 28,076 \\
\hline Jarak pengelasan & 2,172 & 7,249 & 0,007 & 8,776 & 1,806 & 42,660 \\
\hline Penggunaan APD & $-1,752$ & 4,892 & 0,173 & 0,173 & 0,037 & 0,819 \\
\hline Constan & $-3,652$ & 4,098 & 0,026 & 0,026 & & \\
\hline
\end{tabular}

Berdasarkan hasil analisis pada tabel 3 variabel memenuhi syarat untuk masuk kedalam analisis multivariate dengan nilai $\rho<0,25$. Setelah dilakukan menggunakan analisis regresi logistik, diperoleh hasil bahwa variabel yang berpengaruh terhadap keluhan subjektif fotokeratitis lama paparan ( $\rho_{\text {value }}=$ $0,012, \mathrm{OR}=6,49095 \% \mathrm{Cl}=1,500-28,079$ ) yang artinya lama paparan yang berisiko memiliki peluang mengalami keluhan subjektif fotokeratitis sebesar 6,940 kali di banding dengan responden yang memiliki lama paparan yang tidak berisiko. Jarak pengelasan ( $\rho_{\text {value }}=$ 0,007, OR= 8,776 95\% Cl=1,806-42,660), yang artinya jarak pengelasan yang berisiko tinggi memiliki peluang mengalami keluhan subjektif fotokeratitis sebesar 8,776 kali lebih besar dibanding dengan responden yang memiliki jarak pengelasan yang berisiko rendah. Penggunaan APD ( $\rho_{\text {value }}=0,027, \mathrm{OR}=0,173$ $95 \% \mathrm{Cl}=0,037-0,819)$ yang artinya variabel penggunaan APD yang tidak memenuhi syarat berisiko, memiliki peluang mengalami keluhan subjektif fotokeratitis sebesar 0,173 kali lebih besar dibanding dengan responden yang patuh menggunakan APD.

\section{Penutup}

Berdasarkan hasil penelitian dan pembahasan dapat disimpulkan bahwa ada 
hubungan antara lama paparan, jarak pengelasan, dan penggunaan APD dengan keluhan subjektif fotokeratitis pada pekerja pengelasan di Kota Kendari Tahun 2020. Serta tidak ada hubungan antara getaran dengan keluhan subjektif fotokeratitis pada pekerja pengelasan di Kota Kendari Tahun 2020. Ada pengaruh antara lama paparan, jarak pengelasan dan penggunaan APD dengan keluhan subjektif fotokeratitis pada pekerja pengelasan di Kota Kendari tahun 2020

Adapun saran untuk penelitian ini yaitu pihak industri diharapkan untuk menerapan SOP, undang-undang tentang $\mathrm{K} 3$, peraturan tentang NAB getaran dan NAB radiasi sinar UV yang di pekenankan di area bengkel las. Untuk peneliti selanjutya disarankan untuk meneliti faktor penyebab keluhan subjektif fotokeratitis lainnya seperti, faktor individu dan bahaya radiasi sinar ultraviolet pada pekerja pengelasan

\section{Daftar Pustaka}

1. Tarwaka. (2015) Ergonomi Industri, Dasar-dasar Pengetahuan dan Aplikasi di Tempat Kerja. Edisi Ke-2. Surakarta: Harapan Press.

2. Nurgazali. (2016). Gambaran Faktor Risiko Sindrom Photokeratitis pada Pekerja Las di PT. Industri Kapal Indonesia (Persero) Kota Makassar. IOSR Journal of Economics and Finance.

3. Arsanjani. (2017) Faktor yang Berhubungan Dengan Kejadian Sindrom Photokeratitis pada Pekerja Las Listrik di Kelurahan Romang Polong Kecamatan Somba Opu Kabupaten Gowa. (skripsi) Makassar: FKIK UIN Alauddin Makassar.

4. Yuda NAP. (2013). Hubungan Lama
Paparan dan Penggunaan Alat Pelindung Diri (APD) Terhadap Keluhan Subjektif Fotokeratitis pada Pekerja Las di Bengkel Las Wilayah Kecamatan Tanjung Karang Barat Kota Bandar Lampung. J Chem Inf Model.

5. Laila NN. (2017). Keluhan Subjektif Photokeratitis pada Mata Pekerja Las Sektor Informal di Kelurahan Cirendeu Dan Ciputat Tangerang Selatan. Kesehatan Masyarakat

.2017;(978-979-3812-41-0):199-204.

6. Yen YL, Lin HL, Lin HJ, Chen PC, Chen CR, Chang GH, et al. (2004). Photokeratoconjunctivitis caused by different light sources. Am J Emerg Med.

7. Kurniawan A. (2017). Gejala Fotokeratitis Akut Akibat Radiasi Sinar Ultraviolet (Uv) pada Pekerja Las di PT. Pal Indonesia Surabaya. Ikesma. 2017;13(1):22-31.

8. Odie Prino Secaria $B$, Ismi Hartanti R, Dewi Prahastuti Sujoso A. (2015) Hubungan Paparan Getaran Mesin Gerinda dengan Terjadinya Keluhan Hand Arm Vibration Syndrome pada Pekerja Mebel Informal. $J$ Kesehat Masy Univ Jember.

9. Novi, Darmawan A, Pattipawaej OC. (2016). Analisis Pengaruh Getaran Terhadap Konsentrasi Pekerja. Semin Nas Sains dan Teknol.

10. Wahyuni T. (2013). Faktor Risiko yang Berhubungan dengan Kejadian Konjungtivitis pada Pekerja Pengelasan di Kecamatan Cilacap Tengah Kabupaten Cilacap. J Kesehat Masy FKM UNDIP. 2013 